\title{
THE EFFECT OF THE LEVEL OF
}

APPLICATION OF SELECTION AND

BREEDING CRITERIA AS FACTORS OF

SUSTAINABLE SHEEP PRODUCTION ON

PRODUCTIVE TRAITS OF SHEEP IN

EXTENSIVE REARING SYSTEM**

\author{
M. P. Petrović ${ }^{*}$, Lj. Sretenović ${ }^{1}$, D. Ružić Muslić ${ }^{1}$, C. Mekić ${ }^{2}$, N. \\ Maksimović $^{1}$ \\ ${ }^{1}$ Institute for Animal Husbandry, Belgrade, Serbia \\ ${ }^{2}$ Faculty of Agriculture, Belgrade, Serbia \\ *Corresponding author: Milan P. Petrović, milanppet@yahoo.com \\ **Original scientific paper
}

\begin{abstract}
For the purpose of realization of the project of development of sustainable sheep production systems, in this paper, the major influences on production parameters of sheep in conditions of Stara Planina Mountain are investigated. Using the knowledge of gene effects, with good breeding programs, it is possible to realize, with more or less success, planned annual genetic progress of traits which are of interest to the breeders. This relates first of all on gain of lambs and milk yield in sheep. As already known, traits of body development and milk production vary depending on the factors of hereditary nature, but also factors of the environment. Therefore, the level of application of selection-breeding criteria is of great practical importance, which is confirmed also in this paper, and level of significance was statistically confirmed. Also, for complete creation of the program of improvement of sheep milk and meat production it is important to be aware of the effect of the breed itself, as well as of type of birth on production parameters, which was taken into consideration during investigation, processing and presentation of data in this paper. Obtained results show that majority of observed factors had significant effect on realized production of sheep.
\end{abstract}

Key words: sheep, rearing system, selection, breeding, meat, milk 


\section{Introduction}

For the purpose of development of sustainable sheep production, it is necessary to apply criteria of selection and breeding (Duguma et al., 2002, Petrović et al., 2005, Petrović, 2007). In spite of adequate organization, this is not easy to achieve, when we know that whole procedure depends on: the development of sheep production, especially in regard to the level of application of selection and breeding criteria, ownership structure of farms, level of motivation of breeders for improvement of production, etc. (Kukovics and Javor, 2001, Gabina 2006, Ružić-Muslić et al., 2005, Petrović et al., 2008).

Production of meat and milk in certain population can be increased year by year, if selection is carried out systematically through planned improvement in breeding (Petrović, 2000).

Application of the plan for sheep improvement must include and acknowledge all parameters which could influence the results, presence of certain balance in genetic progress between the nucleus and commercial herd is very important.

Production of meat and milk on Stara Planina Mountain is traditional and historically mainly based on rearing of Pirot Pramenka as local population in extensive production systems. This breed, like majority of local populations has very solid genetic potential for gain in lambs and milk yield of sheep, but in order for this genetic potential to be exhibited, it is necessary to apply higher criteria of selection and breeding, which mainly isn't the case. Beside Pramenka, since second half of the 20th century, on the territory of Stara Planina Mountain located in the municipality of Pirot, new population has been introduced - Pirot improved sheep. It is reared mainly as Pramenka, although these two breeds differ completely from the genetic aspect.

Objective of this paper is to point out the practical importance of the level of application of selection and breeding criteria in production of meat and milk of two sheep breeds mentioned previously in extensive rearing system.

\section{Material and method}

Investigations are the main part of the project which was realized partially on the territory of Stara Planina Mountain - Visok. Sheep included in this research were representatives of following populations:
1) Pirot Pramenka
2) Pirot improved sheep 
Investigation included 600 sheep, on two farms, 150 heads of both studied populations or 300 heads per each farm. In regard to the level of application of selection and breeding criteria, farms were marked A and B. On farm A, higher level of selection and breeding was applied compared to farm B. Control of productive traits on both farms was realized using standard procedures, once a month. Of environmental factors, the effects of application of different selection criteria and effects of application of different breeding criteria were observed. Also, type of birth of lambs was included in the investigation. Traits of body development of progeny from birth to weaning at the age of 90 were controlled and milk traits of sheep during lactation of 180 days.

In processing of data, and for the purpose of analysis of stated criteria and effects, the procedure of following linear model was applied, method of least squares:

$$
Y=\mu+P i+S j+T k+b_{1}+e i j k \text {, where symbols have following meanings: }
$$

$\mu$ - population average

Pi- effect of the observed population

$\mathrm{Sj}$ - effect of the selection and breeding criteria

Tk- effect of type of birth

$b_{1-}$ regression coefficient

eijk- undetermined effects

\section{Results and discussion}

From table 1 we can see that body mass of investigated lambs varied depending on the farm, breed and type of birth. Namely, the highest body mass of $4,10 \mathrm{~kg}$ in first measuring immediately after birth, then $10,01 \mathrm{~kg}$ at the age of 30 days and $25,72 \mathrm{~kg}$ at weaning at the age of 90 days, was established in lambs of Pirot improved population. These lambs were reared on farm A, where higher criteria of selection and breeding had been applied. Differences in body mass between lambs shows that there is significant influence of all observed effects, from population and selection and breeding criteria to type of birth, which was statistically significant $(\mathrm{P}<0,05$ and $\mathrm{P}<0,01)$. Especially significant is the effect of application of selection-breeding criteria, since they are key to genetic improvement, and development of sustainable sheep production, as stated by Petrović, 2000, Gabrilidis et al., 2000, Grant et al., 2001, Hanford et al., 2002, Petrović, 2007. 
Table 1. Average (LSM) values of body weight of lambs

\begin{tabular}{|c|c|c|c|c|c|c|c|}
\hline \multicolumn{2}{|c|}{ Effect } & \multicolumn{2}{|c|}{$\begin{array}{l}\text { Body weight } \\
\text { 1.day, kg }\end{array}$} & \multicolumn{2}{|c|}{$\begin{array}{c}\text { Body weight } \\
\text { 30.day, kg }\end{array}$} & \multicolumn{2}{|c|}{$\begin{array}{l}\text { Body weight } \\
\text { 90.day, kg }\end{array}$} \\
\hline \multirow[t]{3}{*}{ Farm } & \multirow{3}{*}{$\begin{array}{l}\text { Type of } \\
\text { birth }\end{array}$} & & & & & & \\
\hline & & & neep & Bree & & Bre & heep \\
\hline & & 1 & 2 & 1 & 2 & 1 & 2 \\
\hline \multirow[t]{2}{*}{ A } & single & 3,45 & 4,10 & 8,26 & 10,01 & 22,56 & 25,72 \\
\hline & twins & 3,28 & 3,97 & 8,11 & 9,86 & 21,03 & 23,53 \\
\hline \multirow[t]{2}{*}{ B } & single & 3,23 & 3,96 & 7,86 & 9,79 & 21,55 & 24,11 \\
\hline & twins & 3,18 & 3,79 & 7,51 & 9,62 & 20,19 & 23,03 \\
\hline
\end{tabular}

Milk yield and milk traits of sheep were also different, which is presented in table 2 .

Table 2. Average (LSM) values of milk yield and milk quality of sheep

\begin{tabular}{|c|c|c|c|c|c|c|c|}
\hline \multicolumn{2}{|c|}{ Effect } & \multicolumn{2}{|c|}{ Milk, kg } & \multicolumn{2}{|c|}{ Fat, \% } & \multicolumn{2}{|c|}{ Protein, \% } \\
\hline \multirow{2}{*}{ Farm } & \multirow{2}{*}{$\begin{array}{l}\text { Type of } \\
\text { birth }\end{array}$} & & & & & & \\
\hline & & & $\begin{array}{c}\text { sheep } \\
2\end{array}$ & $\begin{array}{c}\text { Bree } \\
1\end{array}$ & 2 & & heep \\
\hline \multirow[t]{2}{*}{ A } & single & 77,99 & 77,15 & 7,19 & 6,98 & 5,39 & 5,44 \\
\hline & twins & 79,87 & 78,61 & 7,00 & 7,06 & 5,68 & 5,71 \\
\hline \multirow{2}{*}{ B } & single & 72,11 & 71,92 & 7,18 & 7,12 & 5,68 & 5,66 \\
\hline & twins & 73,25 & 72,44 & 6,99 & 6,96 & 5,81 & 5,78 \\
\hline
\end{tabular}

Very significant difference $(\mathrm{P}<0,01)$ is observed in regard to quantity of milk in lactation due to the influence of application of different selection and breeding criteria on observed farms. The highest milk yield of $79,87 \mathrm{~kg}$ was recorded for sheep on farm A, in population of Pirot Pramenka, in these female breeding animals who gave birth to twins. Also, level of application of selection 
and breeding criteria and type of birth had very significant effect $(\mathrm{P}<0,01)$ on quantity of milk in sheep of Pirot improved breed.

In regard to quality of milk, i.e. content of fat and protein, values of mutual differences are negligible and statistically insignificant $(\mathrm{P}>0,05)$ in regard to all three observed effects. Numerically, slightly higher fat content was recorded in heads of breed 1, and of protein in heads of bred 2 .

Results of these researches are in concordance with results obtained by other authors (Marie et al., 1996, Sheat et al., 2001, Petrović, 2007).

\section{Conclusion}

Based on carried out investigations, processed and presented results, the following few conclusions can be made:

- Body mass of investigated lambs varied depending on the farm, breed and type of birth. The highest body mass of $4,10 \mathrm{~kg}$ at birth, $10,01 \mathrm{~kg}$ at the age of 30 days and $25,72 \mathrm{~kg}$ at the age of 90 days, was established in lambs of Pirot improved population.

- There is significant influence of observed effects, from population, level of application of selection and breeding criteria to type of birth, on body mass of lambs which was statistically confirmed $(\mathrm{P}<0,05$ and $\mathrm{P}<0,01)$.

- Level of application of selection and breeding criteria and type of birth had very significant effect $(\mathrm{P}<0,01)$ on quantity of milk of investigated sheep. The highest milk yield of 79,87 kg was recorded for sheep on farm A, in population of Pirot Pramenka.

- The influence of undetermined effects on quality of milk, i.e. fat and protein content is negligible, and values of mutual differences were statistically insignificant $(\mathrm{P}>0,05)$ 


\section{UTICAJ NIVOA PRIMENE SELEKCIJSKIH I ODGAJIVAČKIH KRITERIJUMA KAO FAKTORA ODRŽIVOG OVČARSTVA NA PROIZVODNE OSOBINE OVACA U EKSTENZIVNOM SISTEMU GAJENJA}

M. P. Petrović, Lj. Sretenović, D. Ružić Muslić, C. Mekić, N. Maksimović

\section{Rezime}

Za razvoj održive ovčarske proizvodnje, između ostalog, neophodna je primena visokih kriterijuma selekcije i odgajivanja. Cilj ovog rada je da ukaže na praktičan značaj nivoa primene kriterijuma selekcije i odgajivanja $u$ proizvodnji mesa i mleka ovaca u ekstenzivnom sistemu gajenja na Staroj planini.

Proizvodnja mesa i mleka ovaca na Staroj planini je tradicionalna i istorijski posmatrano, uglavnom je zasnovana na gajenju pirotske pramenke, kao lokalne populacije u ekstenzivnim proizvodnim sistemima. Ova rasa kao i većina lokalnih populacija poseduje solidan genetski potencijal za prirast jagnjadi i mlečnost ovaca, ali da bi se taj potencijal ispoljio, potrebna je primena viših kriterijuma selekcije i odgajivanja, što uglavnom nije slučaj. Pored pramenke od druge polovine XX veka na području pirotskog dela Stare planine uvedena je u primenu i nova populacija-pirotska oplemenjena ovca. Ona se takođe u većini slučajeva gaji kao i pirotska pramenka, mada ove dve rase u genetskom smislu imaju veoma malo zajedničkog.

Kao što je poznato, osobine telesnog razvoja i mlečnosti ovaca variraju u zavisnosti od mnogih faktora nasledne prirode ali i različitih spoljnih uticaja. Zato je nivo primene selekcijsko odgajivačkih kriterijuma, od velikog praktičnog značaja, što potvrđuju i rezultati istraživanja u ovom radu, a što je takođe i statistički potvrđeno. Pored toga za kompletno kreiranje programa unapređenja proizvodnje mesa i mleka ovaca, značajno je poznavanje uticaja same rase, kao i tipa rođenja na proizvodne parametre, o čemu se tokom istraživanja, obrade i prikazivanja dobijenih podataka vodilo posebno računa. Dobijeni rezultati istraživanja pokazuju da je većina posmatranih faktora imala značajan uticaj na ostvarenu proizvodnju. 


\section{References}

DUGUMA, G., SCHOEMAN, S.J., CLOETE, S.W.P., JORDAAN, G.F (2002): Genetic and environmental parameters for ewe productivity in Merinos. S. Afr. J. Anim. Sci.,; 32: 154-159.

GABINA D (2006): The future of sheep and goat production in Europe: prospects within the framework of new support regimes and market conditions. Small Ruminant Research. Vol 62 Iss.3, 159-165.

GABRILIDIS G, PAPADOPOULOS T,GEORGOUDIS A.(2000): Estimation of genetic parameters for production traits of chios sheep using a multitrait animal model. Livestock production science, 66,3, 217-221. Lidga C,

GRANT W. MONTGOMERY, SUSAN M. GALLOWAY, GEORGE H. DAVIS KENNETH P. MCNATTY(2001): Genes controlling ovulation rate in sheep. Reproduction 121, 843-852

HANFORD, K.J., VAN VLECK, L.D., SNOWDER, G.D. (2002): Estimates of genetic parameters and genetic change for reproduction, weight, and wool characteristics of Columbia sheep. J. Anim. Sci.,;80: 3086-3098.

KUKOVICS S, JAVOR A. (2001): Prospects for small ruminant production and consumption in Eastern Europe, Proceedings of the 52nd Annual Meeting of the EAAP, vol. 7 Budapest, Hungary, 26-29 August (2001), p. 251.

MARIE C., BUCqUIER F., BANILLET F. (1996): Influence du potential laitiez sur les composantes de l'efficacite alimentaire de brebis lacaune. In: Institute de l'Elevage (ed) 3eimes Rencontres Resherches Ruminants, Paris, 4-5 Decembre 1996, Paris, vol. 3, 297-300.

PETROVIC P.M. (2000): Genetika i oplemenivanje ovaca. Naučna, Beograd, $365 \mathrm{pp}$

PETROVIĆ M.P., PETROVIĆ C.V. (2005): Sheperding and sheep production in the region of mountain Stara planina-Serbia. 3.rd World Congress of Shepherds. Spain, 21-24. september. Book of Communications, 27-30.

PETROVIC P.M (2007): Sustainable sheepbreeding (Održivo ovčarstvo). Institute for Animal Husbandry, Belgrade, 256 p.p.

PETROVIĆ P.M, SRETENOVIĆ LJ, ALEKSIĆ S, MUSLIĆ RUŽIĆ D, ŽUJOVIĆ M, MAKSIMOVIĆ N (2008): Application of sustainable systems for milk production on small farms. Biotechnology of Animal Husbandry,5-6, 7176.

RUŽIĆ-MUSLIĆ D., NEGOVANOVIĆ D., PETROVIĆ M.P. (2005): Effect of different concentrations of diets for fattening lambs on degradability of nutritive substances. Journal of Animal Science,5, 74-78.

SHEATH G.W., COULON J.B, YOUNG O.A. (2001): Grassland management and animal product quality, Proceedings of the XIX International Grassland Congress Sao Paulo, Brazil pp. 1019-1026. 